\title{
MARY TUDOR - FROM THE PAGE TO THE SCREEN
}

\author{
THE VISUAL TRANSPOSITION AND \\ TRANSFORMATION OF QUEEN MARY I OF \\ ENGLAND IN CARLOS, REY EMPERADOR
}

Elizabeth Evenden-Kenyon

University of Oxford

elizabeth.evenden-kenyon@mod-langs.ox.ac.uk

\begin{abstract}
This article explores representations of Mary I of England, wife of Philip II of Spain. Specifically, it examines the portrayal of the queen - perhaps most famously known by the epithet 'Bloody Mary' - in the TV series Carlos, Rey Emperador (2015-2016), and in its associated online supporting materials. It details how textual representations of Mary underpin European visual depictions of the queen, and considers the ways in which Mary transcends stereotypical, quintessentially English-language portrayals of Mary for Spanish and Portuguese audiences. In doing so, it posits wider observations on the mnemonic strategies underpinning the series Carlos, Rey Emperador, and its different framings for Spanish and Portuguese audiences on the Internet.
\end{abstract}

Keywords: Mary/María, Tudor, Carlos, Rey Emperador, TVS

\section{Introduction}

It's now a decade since the scholar Cynthia Herrup assured members of the American Historical Association that the twenty-first century is an age in which early modern history is considered sexy; we can now say with conviction, she declared, that the "Tudors are a hot dynasty." Her analysis of the marketability and relative 'hotness' of England's monarchy for much of the sixteenth century was, of course, based on the astonishing popularity of the TV series The Tudors, which first aired on English-language channels in $2007 .{ }^{1}$ Hot Tudors have become big, voluptuous business in the English-speaking world.

Yet in that arena, an enduring image of one of England's queens remains: that of 'Bloody' Mary - an unattractive, 'hysterical' woman, either seen as a foolish woman at the mercy of her faith, her emotions, and foreigners, or simply as a blood-thirsty monster whose cruelty knew no bounds. ${ }^{2}$ Mary was born in 1516 and was the daughter of Henry VIII and his first wife, Katherine of Aragon. She became queen after the death of her half-brother, Edward VI, and reigned for just five years: from 1553 until 1558. She married Philip of Spain in 1554. 


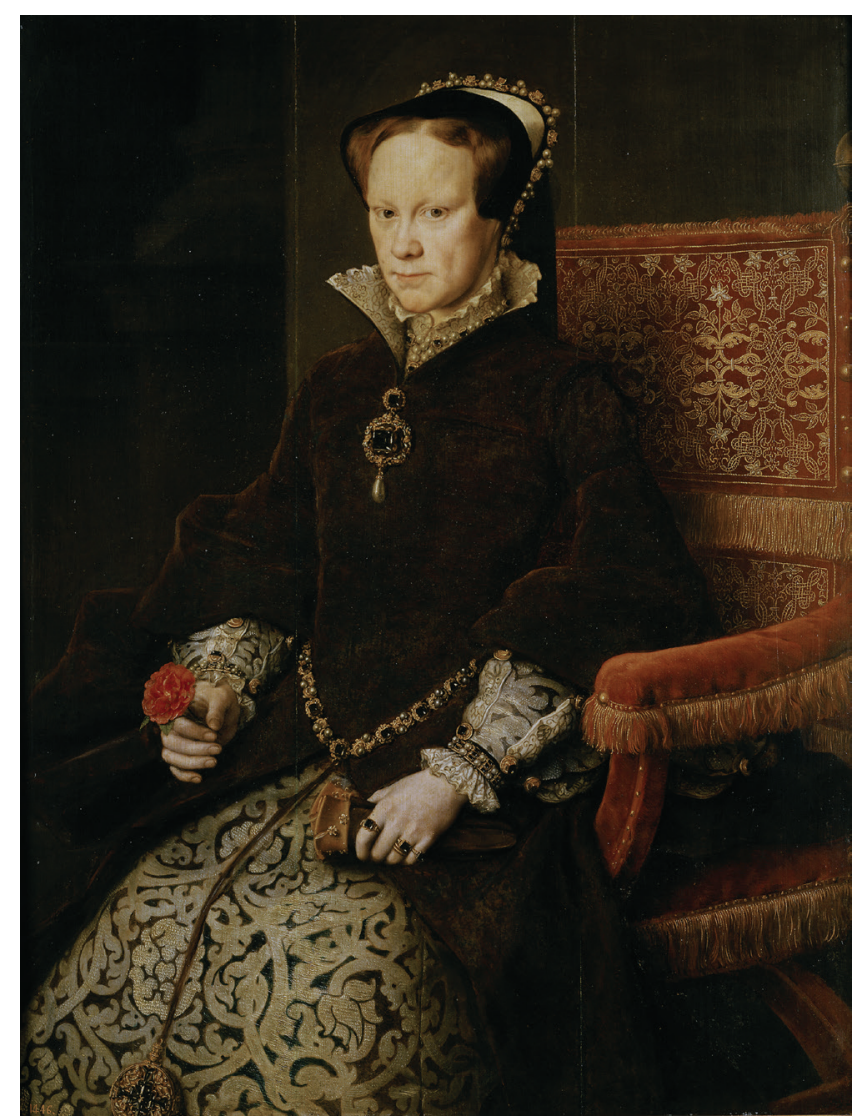

Figure 1. Portrait of Queen Maria I of England (1516-1558), daughter of King Henry VIII (Credit: Wikimedia Commons)

This article will consider three key areas in relation to Mary's reputation and screen presence. Firstly, I explore where this English-language nomenclature - 'Bloody Mary' - came from, and how historians have assessed and reassessed Mary's queenship and femininity in their textual depictions. Secondly, I discuss history and revisionism in the series Carlos, Rey Emperador (TVE, 2015-2016), including the entertainment and memory strategies the series and its associated Spanish and Portuguese online materials. Thirdly, I look more closely at the portrayal of Mary Tudor in Carlos, Rey Emperador: her femininity and relationship with her Spanish husband, Philip, and how this presentation relates to Spanish and Portuguese national memory of this royal couple, and why, for Spanish and Portuguese audiences, this English queen is presented as more than a little 'caliente'.

\section{Mary Tudor in English-Language Historiography}

Mary's reputation in the English-speaking world, for a long time, has been drenched in "religious bigotry and cruelty."3 Much of that hostility was established by an overtly-Protestant assessment of the English Reformation in both mainstream and academic literature, written in English. The Protestants were seen to have 'won' in England, and Catholics needed to accept that Mary was forever to blame for the deaths of hundreds of Protestants during her reign. These executions were seared into English memory by the enduring success and vivid images of burning portrayed in John Foxe's Acts and Monuments, more popularly known as the 'Book of Martyrs.'

First printed in 1563, this martyrology is a classic piece of Protestant propaganda, urging English readers and viewers to remember the more than 300 people who died for their Protestant faith during the reign of Mary and Philip. Foxe's 
book has remained consistently popular for centuries, in a variety of formats. During the reign of Queen Victoria (1837-1876), in whose reign Catholic emancipation became a possibility and then a reality, abridged editions of Foxe's martyrology proliferated, and they often included prefaces by editors who were keen to hold Mary personally responsible for the 'persecutions' enacted during her reign. ${ }^{5}$

But has she always been seen as solely to blame for these burnings? Recent historical analysis suggests not. Writing early in Elizabeth l's reign, Foxe steers clear of directly blaming the queen, who was, after all, seen as the rightful queen of England, anointed by God. The ‘Bloody Mary myth' actually only took meaningful hold in the late nineteenth century, during Victoria's reign, due, in part, to the work of historians such as A.F. Pollard and James Anthony Froude; editors of the abridged editions merely followed suit. In the twentieth century, scholars such as David Loades described Mary as an 'hysterical' queen (an interpretation emphasised by Froude); Loades repeated and reinforced this portrayal in his 1992 biography of the queen, so that 'Bloody Mary', the 'hysterical', vengeful woman, by the 1990s, was ubiquitous in English-language printed historiographical writing. ${ }^{6}$

It was into this climate that the English-language film Elizabeth (1998) was released. Written by Michael Hirst and directed by Shekhar Kapur, this cinematic incarnation sees Cathy Burke portraying Mary in her final years. It reinforces all that was allegedly 'Bloody' and 'hysterical' about this English queen, lifting Loades' description off the page and onto the screen, ensuring that, by the close of the twenty-first century, the Victorian propaganda machine still stalked and dominated the public imagination.

\section{María Tudor in Spanish Historiography}

Perhaps unsurprisingly, in early modern Spain, observers provided a counter-narrative to the English Protestant vitriol. ${ }^{7}$ In 1599, for example, Diego de Yepes, Bishop of Tarazona, published his Historia particvlar de la persecución de Inglaterra ('partial history of the persecution in England' [covering the years 1534-1570]). The Bishop describes Philip's English bride as 'the saintly queen' (Ia santa Reyna), who, with Philip, had done so much to purge the Tudor kingdoms of heresy. ${ }^{8}$

Fast-forward to the early twentieth century, and in 1914, Julián Juderías published his highly influential work, La leyenda negra de España (the black legend of Spain), which attacked English (as well as French and Dutch) interpretations and claims about Spanish intellectual, political and religious life during the sixteenth century. Juderías' worked highlighted how the creation of Mary's reputation as 'bloody' and cruel was a direct result of a systematic, long-lasting campaign to denigrate Spanish activities and alliances during the sixteenth century. ${ }^{9}$

Throughout the 1970s and 1980s, common perceptions of Mary Tudor in Spain became influenced by her portrayal in Fernando Gonzalez-Doria's substantial volume, Las Reinas de España [The Queens of Spain]. ${ }^{10}$ Gonzalez-Doria paints Mary as a sickly, unattractive woman, whose physical appearance clearly made an impression upon Philip at their first meeting - for all the wrong reasons: "Mary had a furrowed face; she was so skinny that her dress seemed to dance about her - and this was a very serious flaw at a time when women were being asked if they were not beautiful they would at least be plump" (Maria tenía el rostro surcado de arrguas, era tan flaca que el vestido parecía bailarle - y esto era un defecto gravísimo en una época en la que a las mujeres se les pedía que si no eran bellas procurasen al menos ser rollizas. $)^{11}$ Mary's portrayal is that of a pathetic individual, destined to make a sad end. Ultimately, for Gonzalez-Doria, she was a short chapter in the life of a magnificent king.

Yet the new millennium has brought reassessments of Mary's demeanor and queenship, detailing a clear departure from previous assessments. María Jesús Pérez Martín views Mary as much more than just a barren wife to Philip: rather, she was a worthy queen, deserving of detailed analysis in her own right. In María Tudor. La Gran Reina Desconocida [Mary Tudor: The Forgotten Queen] (2006), Pérez Martín does much to rehabilitate Mary as a strong, determined woman who reigned honorably and successfully, despite her physical adversities. Her legacy, for Pérez 
Martín, is not as a 'bloody' queen (it is worth noting how little attention she pays to the burnings in England) but as a sanguine, mighty ruler. ${ }^{12}$ Despite its substantial size (totaling 927 pages), this biography has nonetheless reached three editions and moved into paperback in the ten years since its first issue.

In a further collective study of the wives of Philip II (Las cuatro esposas de Felipe II [The four wives of Philip II], 2011), Antonio Villacort depicts Mary as physically fragile but a spiritually strong woman, who equaled her husband in piety. ${ }^{13}$ But perhaps the most popular depiction in book format today is that provided by the scholar Maria Pilar Queralt del Hierro in Las Mujeres de Felipe II: Deber y passion en la casa del rey (The Wives of Philip II: Duty and Passion in the King's House). ${ }^{14}$ This beautifully presented - and highly accessible - volume does much to elucidate the English context during the reign of Philip and Mary for a Spanish, lay audience. Here Mary is depicted as a loyal, loving and submissive wife ("Mary was willing to grant whatever her young husband asked of her"' (María... estaba dispuesta a conceder todo lo que su joven esposo le pidiera): - one who turned 'a deaf ear' to rumours of his infidelities and palpable lack of devotion to her (María hizo oídos sordos a los rumores). ${ }^{15}$ Again, the central emphasis here is on the pity we should feel for Mary, as a women whose health and husband failed her. Here we now have a queen who is rehabilitated in the eyes of the public, and worthy of scrutiny under a twenty-first century world view.

\section{Mary Tudor on Screen: A $21^{\text {st }}$-Century Fox?}

By the time Elizabeth's sequel, Elizabeth: The Golden Age, appeared in 2007, historical analysis of the queen had begun to question such a two-dimensional assessment. ${ }^{16}$ That same year, The Tudors began airing on English and American television networks, with Sarah Bolger playing the young Mary from Season 2 onwards, appearing in 23 episodes from 2008 until 2010. This was the same year that Bell and Gray provided an important assessment of the process whereby historical representations are mediated, shaped and transformed through television. They detail how "the medium itself imposes limitations on how and what kinds of history reach the screen."17 The Tudor dynasty may have remained popular but their tired, old, familiar image was ready for revision, if it were to engage with old and attract new audiences. With Mary, the focus was no longer on a withering, childless queen but on a vibrant princess, challenging the sexist, stereotyped version of an English queen depicted by previous generations. Mary now had something to offer to twenty-first century audiences.

Indeed, Gray and Bell's observations about which histories are incorporated into the national story of a nation, which are not, and why, reminds us that, whilst some periods of history may remain popular because of their action and scandal, they can also be open to revisiting with fresh eyes - the eyes of a generation of feminist acclamation and increased female representation. ${ }^{18}$ Issues of identity are generational, and target audiences include each new generation's exposure to their country's past (be it their place or birth or residence). ${ }^{19}$ Television for a new millennium brought a new portrayal of Mary to a new generation of English-language viewers, keen to see something fresh, something appealing to their generation's world view. The modality of national recollection had thus been altered, and a new collective memory begun.

\section{Queen Mary I of England: Historical Revisionism on Television in Spain and Portugal}

Bell and Gray detail the limitations of presenting history on television as being threefold: technological, financial, and cultural. ${ }^{20}$ To produce a landmark historical series requires not only the means by which to overcome the technological and financial burdens inherent in such a vast undertaking as Carlos, Rey Emperador, it also necessitates a bedrock of data upon which - however loosely - a narrative progression can be pinned. Song makes an important observation 
about Spain's "long and complicated relationship with its troubled past" and how this might be overcome for prime time viewing, detailing how "historical distance and rational analyses give way to an emotional understanding of what took place." Appeals to emotion enable programme producers to overcome an awkward cultural hurdle. ${ }^{21}$ The 'memory work' at play in such productions, according to Song, is two-fold, and worth quoting at length:

One highlights an affective reaction to an historical event, while the other points at how this affective response ends up conditioning the way the past is perceived and re-interpreted in the present.... This relationship between past, present, and the personal speaks to the idea that television history becomes an experience in which our personal identification with the lives of historical characters shapes our understanding of the past. ${ }^{22}$

In other words, televised representations of history combine with popular culture to contribute to 'memory production' - one that enables us to feel a manufactured level of connection with historic individuals on an emotional level. ${ }^{23}$

In their work exploring fiction and memory on Spanish and Portuguese television (albeit in relation to the Spanish Civil War), Lafondd et al examine "the modality of recollection used in relation to facts and characters, be they real or imaginary." 24 They argue that television representations of historical events and characters are a vehicle for historiographical reflection: "they are narrative works, which represent the past in television, but also through televisual mediation." 25 If Carlos, Rey Emperador invites viewers to reflect on their nation's history - which de facto includes printed historiography - then that reflection represents the past of Spain and Portugal and the historiography of those nations, as well as the complex relationships between their royal houses.

How then might Spanish and Portuguese television audiences be expected to respond to a televisual depiction of an English queen? How is an emotional response stimulated, to enable viewers to connect with this historical figure? What is her value in the historical, televisual narrative, and her commercial value in sustaining audiences through the episodes in which she appears? ${ }^{26}$

In Carlos, Rey Emperador, Mary appears in her three official roles: as heir to the throne (Princess Mary), as Lady Mary (a subjugated role, removing her from the line of succession, after her father divorces Mary's mother, Katherine of Aragon), and subsequently as Queen. I will focus on the portrayal of Mary as regnant in this series, since this is the period for which her 'Bloody' and 'hysterical' reputation was asserted for so long by English-language historians - a reputation all along at odds with the vast majority of Spanish historiographical accounts. But first, we will consider the 'dual screen' portrayal of Mary in this series: not only in the series itself but also in the supporting, extensive webbased materials intended to support and enhance the television viewer's experience.

\section{Carlos, Rey Emperador: The Series and its Supporting Media}

Carlos, Rey Emperador was directed by Oriol Ferrer, and produced by Diagonal TV for the national broadcaster Televisión Española (TVE). It is a sequel to the successful series Isabel, ${ }^{27}$ and it premiered on 7 September 2015 on TVE's flagship channel, La 1, and ran until the end of January 2016. The series has averaged around 2 million viewers in Spain per episode. ${ }^{28}$

The series has won numerous awards. By way of example, at the Premios Awards of the Asociación de Cronistas de Espectáculos (ACE) in New York during 2016, it won Best Cultural Show of the Year, Best TV Director, and Best Supporting Actor and Actress for two of its cast. ${ }^{29}$ Although viewing figures appear to be lower for airings in other Spanish-language countries, the show has proved immensely popular, and it should be acknowledged as having had a significant impact on its targeted cultural milieu, with social media and mainstream media acting as reasonable signifiers of interest, particularly for younger viewers. ${ }^{30}$ 
E. Evenden-Kenyon, Mary Tudor - From the Page to the Screen

The series' own webpage proffers multi-media activities to stimulate further inquiry into the figures depicted, including a videogame (videojuego) suitable for use on tablets and smartphones. ${ }^{31}$ The additional support is targeted at viewers who are potentially less familiar with the historical context (and the historiography), and also includes 16 episodes about 'El Mundo de Carlos' (the world of Carlos), a mini-series specifically designed to help viewers navigate the plot and extensive dramatis personae. ${ }^{32}$ Similarly, pages are provided on the series' website to enable viewers to read more about the individuals portrayed. ${ }^{33}$

Queen Mary is scrutinised in these supporting materials, such as in the summaries of contents for the individual episodes in which she appears. ${ }^{34}$ Although it plays a relatively minor role in the textual apparatus for the series, the 'Bloody Mary' nomenclature does appear. In the description of a key scene where Lady Mary visits her sick mother (Katherine of Aragon), Mary is described as someone who (in later episodes) will "fulfil the desires of her mother" to become a legitimate and Catholic queen of England. The supporting materials cannot or chose not to resist the nomenclature in their description: "Bloody Mary cumplirá el deseo de su madre." ${ }^{5} \mathrm{It}$ is worth noting the discrepancy here: the supporting materials present details and implant memories that are not supported by the televisual representations themselves.

The penultimate episode of the series - episode 16 - details Mary's fulfillment of her mother's desires: she becomes queen and, as would have no doubt also pleased her mother, she marries a Spaniard. Again, the supporting materials provided by the rtve.es website invite us to think of Mary in a particular way. In her accompanying descriptive materials, the series' historical advisor, Mónica Calderón, draws viewers' and readers' attention to the link between Katherine of Aragon's desires, and their revelation in the penultimate episode. ${ }^{36}$ Calderón describes Mary as "the sad queen in love" (la triste reina enamorada). We see her become queen and marry a Spaniard but it is clear that her happiness will not last. Calderón's supporting materials correctly detail how, at one point, a marriage between Carlos and Mary was considered possible (the Habsburgs were notorious - and paid the price - for their limited blood line and obsession with marrying within their kith and kin). But such an idea is dismissed and Carlos eventually orders his son - much younger than Mary - to unite the two dynasties. ${ }^{37}$

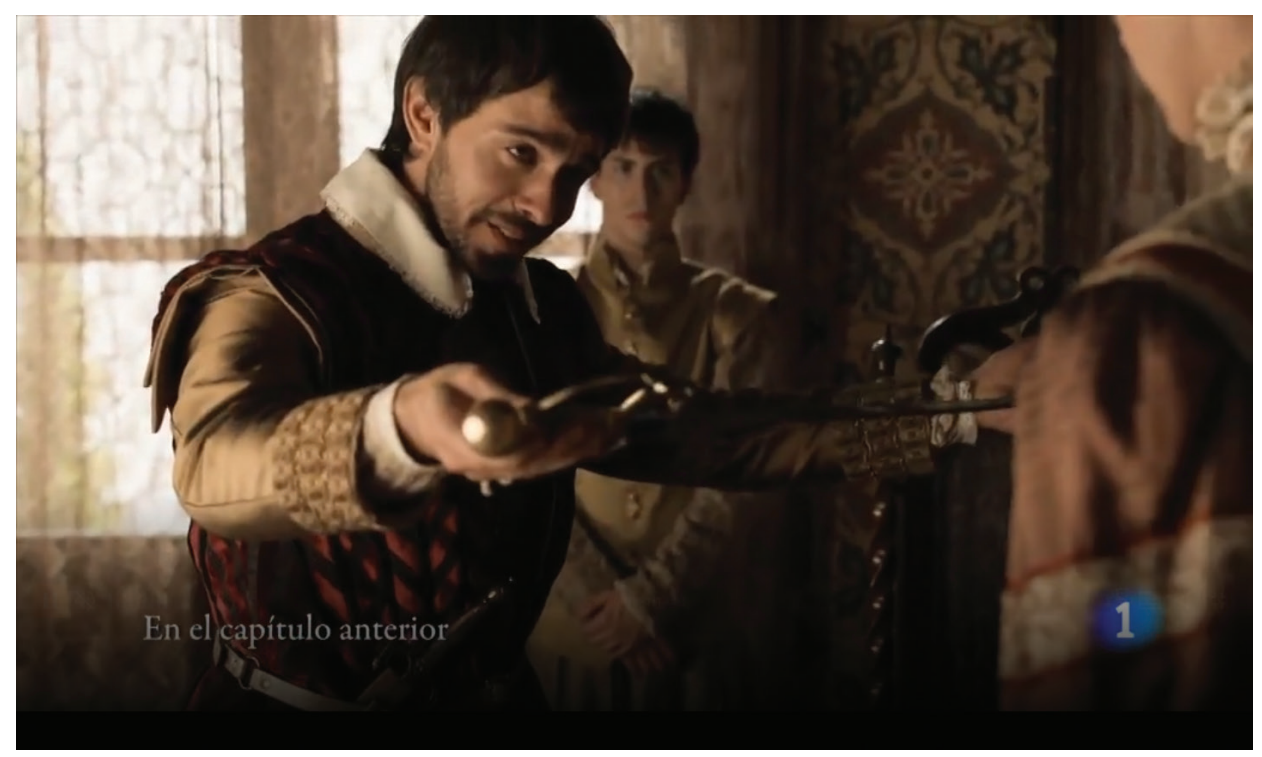

Video 1. Carlos, Rey Emperador, episode 16 
Episodes 16 and 17 detail Mary's reign, first as an unmarried queen and then as Philip's wife. The story does not extend to Mary's death (which occurred not long after the death of Carlos), nor does it detail in any form the burning of heretics in England, which only occurred after her union with the Spanish king. Instead, the focus is upon the couple's inability to conceive. Again, the supporting materials provide insight into how Mary's medical condition began to deteriorate along with hopes of an heir. We are told that she begins to 'decay' (decianiento) and suffer from 'fevers' (fiebres), 'bleeding' (las sangrias), insomnia (el insomnia), with bouts of depression manifesting in crying fits (las crisis depresivas y de llanto) and she turns increasingly pale and thin (está pálida y delgada). ${ }^{38}$ The supporting materials do note that Mary probably died of uterine or ovarian cancer (María Tudor murió probablemente de cáncer de útero o de ovaries), and go so far as to state that, whilst legends may surround certain historical figures, it is important that the bigger story be told (pero detrás de las leyendas e incluso de los hechos contrastados, hay siempre una historia mucho más grande que siempre, siempre, merece ser contada.)

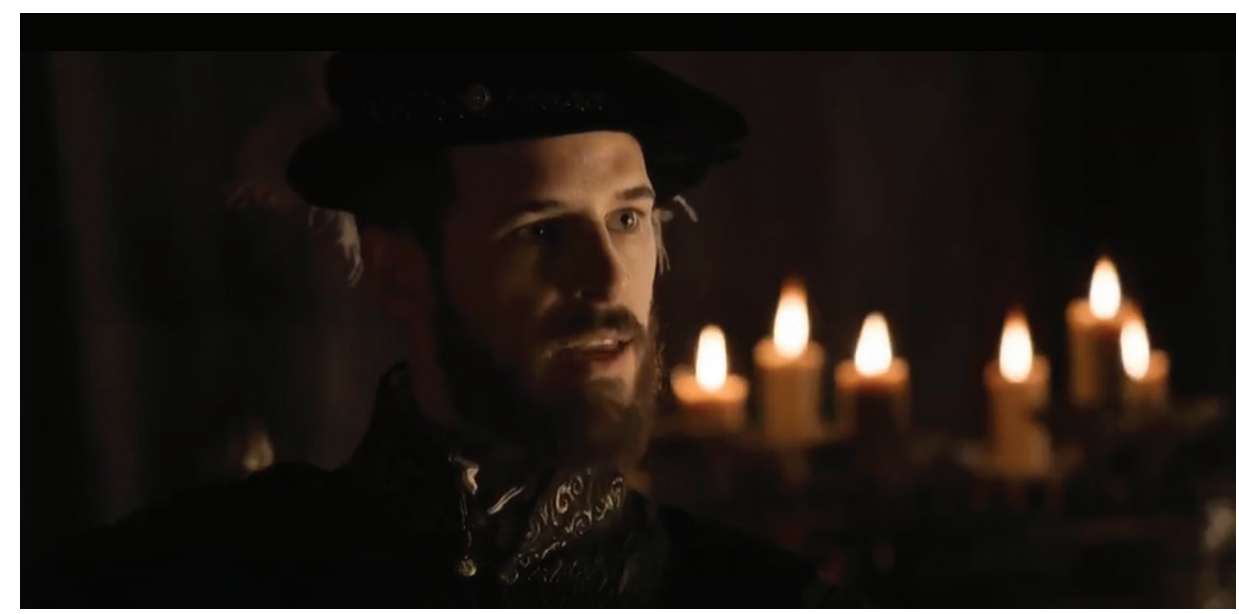

Video 2. Carlos, Rey Emperador, episode 17

Yet none of this particularly tallies with the physical appearance of the queen, as portrayed on-screen by Ángela Cremonte. We see no deterioration in physical condition, only tears and frustration. And no stretch of the imagination could describe Cremonte's physical appearance at any point during Carlos, Rey Emperador as 'ugly, old, skinny and pretty stale' (María es fea, vieja, flaca y bastane rancia), as Calderón suggests. Calderón does describe Philip as the young 'candy that everyone wanted' (el caramel que todos querían), which is evidenced in episode 16, but there are no attempts to portray the unmarried, newly-wed, or sickening Queen Mary as starting out as or progressing towards being a repulsive figure. Cremonte's portrayal exemplifies a fragility but with an enduring level of self-determination. The key points at which her guard drops are when it comes to her physical attraction to Philip.

\section{Mary and Philip: On-screen Chemistry and Authenticity}

The basic portrayal of events leading up to the marriage of Philip and Mary is presented fairly accurately, although a few liberties are taken. Philip originally intended to marry María of Portugal, and in episode 16 he appears captivated by a cameo of her portrait. Still, he worries that beauty is not often accompanied by brains ("Tanta belleza no suele ir 
acompañada de ingenio"). Shortly after this scene, in a discussion with Francisco de Borgia (played by Víctor Clavijo), Philip talks of his increasing fears for his father's ability to judge situations wisely. Francisco asks him if he worries that his continued subjugation to him will "miscarry" his future ("malogre vuestro porvenir"), and Philip agrees. He is advised not to be impotent (presumably, in any sense of the term). Francisco counsels Philip to prepare for the day coming soon - when he will be the most powerful man in Christendom, and that he must act to ensure that his future power does not miscarry. Again, the language utilised is telling. Next in episode 16 we see Philip's grandmother, Juana, tell him that she has never known a family to be so devoid of compassion as her own: "nunca he conocido familia tan desprovista de compasión como esta." 39 Philip finds himself bereft of a response. The stage is thus set for the match between Philip and Mary - including our responses to Philip's treatment of her. Carefully crafted lexical markers reinforce, like omens, what is to come.

Upon the announcement of the death of Edward VI, the young King of England (Mary's half brother), Carlos orders Philip to marry Mary, and the Duke of Alba reaffirms that this must happen, since it will provide Philip with a child who will ensure the continuance of Catholicism in the realm. ${ }^{40}$ And so the Duke of Alba is charged with presenting the Spanish case to Mary in person, where we duly see Mary flustered by his arrival and by the fact that suddenly "the whole of Europe is bent on me marrying" ("europa entera parece empeñada en casarme"). Her behaviour appears a mixture of embarrassment and excitement, with her cheeks flushed and her regal demeanour slipping as she paces the room. She tells Alba that she has already had an offer of a suitor from the French. He asks if the Frenchman can offer the same rank as Philip's impressive CV of titles and dominions, to which she at least physically responds with interest; yet, even then, she declares that, whatever his wealth of titles, he is still "just a man" ("solo un hombre").

Alba's response is magnificent. At this point he plays his ace card and reveals a portrait of Philip, which he has brought with him from Spain. According to Carlos, Rey Emperador, Mary's decision to accept Philip's suit is a direct result of her viewing of this painting. Calderón reinforces this in her accompanying materials. Tiziano Vecelli (Titian) was indeed commissioned to undertake a portrait of Philip for Mary but, in reality, she only witnessed this manifestation of his physical attributes after she had agreed to the union. ${ }^{41}$

On screen, however, it is her attraction to the portrait that seals the deal: not politics, not the desire to secure English loyalty to the Catholic Church, just raw sexual attraction. It is interesting to note that the director, Oriol Ferrer, decides not to show the painting that was commissioned for the episode. It is only shown on the outtake stills on the accompanying website. ${ }^{42}$ I would argue that this is certainly a wise choice: the audience are forced to focus on Mary's response to the portrait, not their own.

As such, the scene functions like Leontes' response to Hermione's statue in The Winter's Tale (Act 5 scene 3): it is not about the statue, it is about the response. As John Edwards notes in Mary I: England's Catholic Queen, Mary's decision to marry was made "not out of carnal affection, but solely for the honour and prosperity of her kingdom". ${ }^{43}$ Carlos, Rey Emperador claims exactly the opposite.

John Edwards, in his biography of Mary (Mary I: England's Catholic Queen, 2011), describes in detail how Philip and his entourage arrived in Southampton to meet Mary in July 1554. The account is based upon detailed archival sources. The party arrived "in the pouring rain which had dogged them since their arrival," making their way to Winchester, where Mary was "lodged in the bishop's Wolvesey castle to await them":

Philip wore a red felt cloak in a vain attempt to keep the rain off his black velvet and white satin clothes and his jewels... After dusk, when they had had supper, came Philip's crucial first encounter with Mary herself. Accompanied by a large number of English and Spanish nobles, he walked to Wolvesey and entered by what Barahona describes as a 'secret door', climbing a winding staircase to the long gallery where the Queen was waiting for him. ${ }^{44}$

Edwards goes on to describe Mary's outfit in detail and the formal introductions made upon his arrival in the gallery. ${ }^{45}$ In Carlos, Rey Emperador, Mary meets Philip the moment he descends from his carriage (his horses having kicked up 
a cloud of sandy dust, dust noticeably more akin to Spanish soil than the soggy roads of Winchester). This initial meeting in person also focuses on Mary's responses to Philip, and his awkwardness in meeting someone who is barely containing her excitement and attraction towards him.

Whilst I take issue with Cigognetti and Sorlin's claim that "written sources do not pose problems" for those seeking to recreate historical events on television, there can be little doubt that the surviving accounts of Mary's first meeting with Philip detail the meteorological conditions of that encounter. ${ }^{46}$ What is portrayed in this scene is demonstrably not "underpinned by evidence" in its setting, although it does utilize "creative licence" to circumnavigate the "limitations" inherent in filming on a wet day in England. ${ }^{47}$

Mary manages to contain her decorum during their marriage ceremony, which is beautifully depicted on location in Winchester Cathedral. Viewers then follow them to their awkward wedding night, one in which Philip finds time secretly to look at a book filled with pornographic woodcuts. We are led to believe that Philip finds himself otherwise lacking the necessary stimuli.

Of course this encounter does not lead to pregnancy and, although Mary later informs Philip that she has lost a son, the Duke of Alba is seen to advise Philip that this miscarriage is but a figure of Mary's imagination. Sex becomes both a weapon and a disappointment as their union progresses. Their sexual encounters are seen to improve as a direct consequence of her acquiescing to the provision of the troupes he needs for the battle at St Quentin. Here we are subject to witnessing a naked Mary Tudor: a lithe and beautifully formed queen at that. (This, of course, is not something viewers have hitherto witnessed in depictions of Mary on screen.) But such encounters are not set to last: we witness Philip leaving Mary to return to the continent, and viewers are left to witness a solitary, inconsolable Mary, without husband, without child, and, perhaps, now without hope.

What viewers are presented with, then, I would argue, is an amalgam of established views of Mary as ultimately a character worthy of pity. She is also presented as far stronger in character and more physically attractive than has hitherto been fore-fronted as central characteristics of this English queen. On camera there is not a hint of that 'Bloody' reputation - a mantle previously so difficult to disrobe her of in England. Instead, Mary (re)enters the Spanish collective memory as an attractive, unfortunate woman - a mere moment in the life of Philip of Spain.

\section{Mary Tudor and Carlos, Rey Emperador in Portugal}

To conclude, it is worth considering how this reputation has been considered on Portuguese television. After all, episodes 16 and 17 represent a key period in Anglo-Spanish and Anglo-Portuguese relations, and the Portuguese dynasty is well represented throughout the series. In Portugal, Carlos, Re Emperador aired in 2016 on SIC Caras, the digital and satellite channel. It received some attention - particularly on the internet - mainly for its portrayal of Isabel of Portugal. For the Portuguese channel, the selling point is Isabel's beauty, not Mary.

Without doubt beauty is the focal point for Portuguese discussions of the women in the life of Philip II. Indeed, the website for the Portuguese airing details how "Isabel of Portugal, considered one of the most beautiful women of her time becomes wife of Carlos, giving birth to his son, Philip II of Spain and Philip I of Portugal" (Isabel de Portugal, considerada uma das mulheres mais bonitas do seu tempo e prima de Carlos, torna-se sua esposa, dando à luz Filipe II, I de Portugal.) The site also justifies why the Portuguese should engage with this series: "The story of Carlos, the grandson of Isabel of Castile and Ferdinand II of Aragon, is also the history of Portugal" (A história de Carlos, $O$ neto de Isabel de Castela e Fernando I/ de Aragão, é também a história de Portugal. $)^{48}$

This marketing strategy raises an important point. Each country viewing Carlos scrutinises how its own country and its historical figures are portrayed. Carlos' selling point, perhaps, for English audiences who are able to understand 
Spanish, is the Habsburg interaction with the English monarchy. The English want to see how a Spanish historical drama has portrays them. Similarly, Portuguese audiences are encouraged to see what it says about their nation. Paul Julian Smith neatly describes television as "a notoriously domestic and everyday medium, prized for its cultural proximity to the national public." 49 And there lies the rub: in the main, as audiences, we remain more comfortable with our homeland than we are with others, when it comes to televising history.

For Portugal, Isabel is the primary selling point but - even in the twenty-first century - it is her physical appearance that warrants attention. Reduce a woman to her physical appearance and it suggests that what she says or does is either irrelevant or has less value. Theirs was, of course, a patriarchal world but this emphasis on beauty oversimplifies female roles and achievements. 'Hotness' continues to outrank accuracy.

The televisual future for Mary remains ambivalent in Spain. In 2020, the Spanish fantasy television series El ministerio del tempo (The Ministry of Time) ran an episode in which the investigative team returned to the sixteenth century. The series, created by Javier and Pablo Olivares, was produced by Onza Partners and Cliffhanger for TVE. It premiered on 24 February 2015, on TVE's main channel, La1. It has amassed a considerable following, made the financially lucrative move to Netflix, and has been acquired by HBO for Spain and Portugal. If the televisual presentation of Mary in Carlos, Rey Emperador made academia hopeful of continued, revisionist portrayals of the queen in the future, El ministerio del tiempo has, for now, quashed such optimism. The episode aired on 19 May 2020 and came with an all too familiar title: 'Bloody Mary Hour. ${ }^{50}$ Mary is depicted as a lonely woman in her marriage to Philip - a man who brags about his lover, and who finds his wife unattractive and boring - but she is also vengeful: she is seen to be responsible for the execution of English Protestant 'martyrs' during her reign. She is also depicted as old beyond her years. Played by Rachel Lascar (born in 1969), her character is made to look older than her own - and Mary's - age: tired, haggard, bitter. Spanish-language reviews of the episode reinforce the image of Mary as the 'bloody' queen (la Reina Sangrienta). ${ }^{51}$ If the representation wheel has turned, 'it has turned quickly. And if the Spanish national memory of Philip II's English bride is to be shaped by writers and directors for entertainment value alone, then the negative stereotype - so omnipresent in English-language portrayals for so long - may hold sway over representations of any revisionist historicism.

\section{Notes}

1. For the most recent detailed discussion of the content and reception of The Tudors, see William B. Robison, eds., History, Fiction, and The Tudors: Sex, Politics, Power, and Artistic License in the Showtime Television Series (New York: Palgrave Macmillian, 2016). It is worth noting that, even here, Mary does not receive her own chapter for analysis.

2. In the 1970s, G.R. Elton's characteristic style usually reserved for the female sex did much to turn academic (and wider) opinion against Mary, describing her as "arrogant, assertive, bigoted, stubborn, suspicious, and (not to put too fine a point on it) rather stupid." In Geoffrey Rudolph Elton, Reform and Reformation: England, 1509-1558 (London: Edward Arnold, 1977 ), 376. In 1992 David Loades repeatedly referred to the Queen (who almost certainly died of some form of gynaecological cancer) as 'hysterical'. In David M. Loades, Mary Tudor: A Life (Oxford: Wiley-Blackwell, 1992), 84-166, 252, 258, 266, and 320. Even after the revisionist school of Marian studies had begun to consider Mary more favourably (see below), Anna Whitelock, in her 2009 biography, could not resist a back-handed (and questionable) compliment, claiming that "in many ways Mary failed as a woman but triumphed as a Queen.” In Anna Whitelock, Mary Tudor: England's First Queen (London: Bloomsbury, 2009$), 309$.

3. Judith M. Richards, "Reassessing Mary Tudor: Some Concluding Points," in Mary Tudor: Old and New Perspectives, eds. Susan Doran and Thomas S. Freeman (London: Palgrave Macmillan, 2011), 206.

4. John Foxe's Acts and Monuments was first published in English in 1563, with further editions in Foxe's life appearing in 1570, 1576, and 1583. See Elizabeth Evenden and Thomas S. Freeman, Religion and the Book in Early Modern England: The Making of John Foxe's Book of Martyrs (Cambridge: Cambridge University Press, 2011).

5. For a discussion of these abridged editions and the propaganda value of Foxe's book to Victorian Protestants, see John Foxe, Samuel Potter and the illustration of the Book of Martyrs' for The Bulletin of the John Rylands University Library (Manchester: Manchester University Press, 2013), 203-230.

6. See Thomas S. Freeman, "Inventing Bloody Mary: Perceptions of Mary Tudor from the Restoration to the Twentieth Century," in Mary Tudor: Old and New Perspectives, eds. Susan Doran and Thomas S. Freeman (London: Palgrave Macmillan, 2011), 78-100. 
7. See Gonzalo Velasco Berenguer, Philip I, King of England and Ireland: Spanish Influence under Habsburg-Tudor Rule, 1554-1558, PhD thesis, University of Bristol, 2016, 20-30.

8. Diego de Yepes, Historia particvlar De la persecución de Inglaterra, y de los martirios más insignes que en ella ha auido, desde el año del Señor 1570. En la qval se descvbren los efectos lastimosos de la heregía, y las mudanças que suele causar en las Repúblicas: con muchas cosas curiosas, y no publicadas hasta ahora, sacadas de Autores graues [A particular history of the persecution of England, and of the famous martyrdoms there, which have increased, since the year of our Lord 1570. And equally the pitiful effects of heresy are here discovered, and the impact it has in the Republics: with many curious things, and not published until now, taken from grave authors] (Madrid: Luis Sánchez, 1599), 11.

9. Julián Juderías, La Leyenda Negra de España [The Black Legend in Spain] (Madrid: La Esfera de los Libros, 1914/2014); for discussion of Mary l's reputation see p. 384.

10. Fernando Gonzalo-Doria, Las Reinas de España [The Queens of Spain] (Madrid: Editorial Cometa, 1978/1981), 103-128.

11. Gonzalo-Doria, Las Reinas de España, 121. For his description of Philip's arrival in England, see pp. 120-121 and cf. with the depiction in Carlos, Rey Emperador, detailed below.

12. María Jesús Pérez Martín, María Tudor. La gran reina desconocida [Mary Tudor: The Great Unknown Queen] (Madrid: Ediciones Rialp, 2008); see especially p. 864.

13. Antonio Villacorta, Las cuatro esposas de Felipe II [The Four Wives of Philip II] (Madrid: Ediciones Rialp, 2011), 45-83, especially p. 77.

14. Maria Pilar Queralt del Hierro, Las Mujeres de Felipe II: Deber y passion en la casa del rey [The Women of Philip II: Duty and Passion in the King's House] (Madrid: EDAF, 2011), 87-110.

15. Pilar Queralt del Hierro, Las Mujeres de Felipe II, 105.

16. For an overview of this shift in perception, see: Susan Doran and Thomas S. Freeman (eds.), Mary Tudor: Old and New Perspectives (Basingstoke: Palgrave Macmillan, 2011).

17. Erin Bell and Ann Gray, "History on Television: Charisma, Narrative and Knowledge," European Journal of Cultural Studies 10 , no. 1 (2007): 113-133.

18. Ann Gray and Erin Bell, History on Television (New York: Routledge, 2013), 187.

19. Ibid.

20. Bell and Gray, "History on Television": 113

21. H. Rosi Song, Lost in Translation: Constructing Memory in Contemporary Spain (Liverpool: University of Liverpool Press, 2016), 59.

22. Ibid., 59 and 94 .

23. Ibid., 94.

24. José Carlos Rueda Laffond, Carlota Coronado Ruiz, Catarina Duff Burnay, Amparo Guerra Gómez, Susana Díaz Pérez, and Rogério Santos, "Parallel Stories, Differentiated Histories: Exploring Fiction and Memory in Spanish and Portuguese Television," VIEW Journal of European Television History and Culture 2, no. 3 (2013): 37-44

25. Ibid.

26. María Gil Poisa, "Commercializing Nostalgia and Constructing Memory in As leis de Celavella," in Televising Restoration Spain: History and Fiction in Twenty-First-Century Spain, ed. David R. George, Jr., Wan Sonya Tang (Basingstoke: Palgrave Macmillan, 2018), 209.

27. Isabe/ was directed by Jordi Frades and produced by Diagonal TV for Televisión Española. This series is based upon the reign of Queen Isabella of Castile (1451-1504). Isabel's marriage to Ferdinand II of Aragon became the basis for the political unification of Spain under their grandson, Charles I. The series was broadcast on La 1 from 2012 to 2014.

28. For the viewing figures per episode see: https://en.wikipedia.org/wiki/Carlos,_rey_emperador

29. Juanho Puigcorbé and Nathalie Poza, http://www.xtrart.es/2016/02/10/la-television-y-el-teatro-espanoles-brillan-en-lospremios-ace-de-nueva-york/ (now cached; last accessed 20 February 2021).

30. Examples of groups on Facebook and Twitter include: Isabel - Carlos, Rey Emperador and Carlos Rey Emperador.

31. See http://www.rtve.es/television/20151009/conoce-videojuego-oficial-carlos-rey-emperador/1235926.shtml

32. See http://www.rtve.es/alacarta/videos/el-mundo-de-carlos/

33. It is worth noting that they do make value judgements on certain characters traits of key individuals portrayed in the series, scoring the relative ambition (ambición), loyalty (lealtad) and action (poder) of characters, nation by nation. See: http://lab. rtve.es/carlos-v/personajes

34. See http://lab.rtve.es/carlos-v/inglaterra/maria-tudor

35. http://www.rtve.es/alacarta/videos/carlos-rey-emperador/catalina-aragon-muere-enrique-vii-casado-ana-bolena-mariaheredera-legitima-bloody-mery/3368107/

36. See http://www.rtve.es/television/20160125/mujeres-felipe-ii-maria-tudor-maria-manuela-portugal-isabel-osorio-putadel-rey/1288004.shtml

37. See the webpage cited in note 36 and compare Calderón's comments with John Edwards, Mary I: England's Catholic Queen (New Haven, CT: Yale University Press, 2013), 179.

38. Cf. with Edwards, Mary I, 269. 
39. On Juana see Yolanda Sheuber, Juana La Reina, Loca de Amor [Juana the Queen: Crazy in Love] (Madrid: Nowtilus, 2007).

40. On the dynamic role of Ferdinand Alvarez de Toledo, the third duke of Alba (1507-82) in Spanish policy and dynastic presentation, see Henry Kamen, The Duke of Alba (New Haven, CT: Yale University Press, 2004).

41. For an account of Mary's receipt of Titian's portrait, see Edwards, Mary I, 179.

42. See http://www.rtve.es/alacarta/videos/carlos-rey-emperador/maria-tudor-bloodymery-embarazo-psicologico/3403500/

43. Edwards, Mary I, 179.

44. Ibid., 185-186.

45. Edwards' depiction of this event is based solidly upon detailed, contemporary accounts. See: Juan de Barahona's account in C.V. Malfatti, The Accession, Coronation and Marriage of Mary Tudor as Related in Four Manuscripts of the Escorial (Barcelona: Sociedad Alianza de Artes Gráficas and Ricard Fontà, 1956), 84, 142, and Calendar of State Papers Spanish, vol. XII, 319-22.

46. Luisa Cigognetti and Pierre Sorlin, "History on Television. The Problem of Sources," in Televising History. Mediating the Past in Post-War Europe, ed. Erin Bell and Ann Gray (New York: Macmillan, 2010), 28.

47. See John Corner, "One Upon a Time...' Visual Design and Documentary Openings," in Televising History. Mediating the Past in Post-War Europe, eds. Erin Bell and Ann Gray (New York: Macmillan, 2010), 17.

48. http://siccaras.sapo.pt/programas/2016-06-02-Carlos-Rei-Imperador (now cached; last accessed 20 February 2021).

49. Paul Julian Smith, Spanish Lessons: Cinema and Television in Contemporary Spain (Oxford: Berghahn Books, 2017 ), 63.

50. Rosa Suria, “'El Ministerio del Tiempo' viaja al... Londres de 1554” ['El Ministerio del Tiempo' travels to 1554 London], Mew Magazine, May 19, 2020, https://mewmagazine.es/el-ministerio-del-tiempo-viaja-al-Iondres-de-1554/

51. Marta Madero, "El Ministerio del Tiempo 4x03: Bloody Mary Hour," TimeJust, May 22, 2020, https://www.timejust.es/series/ el-ministerio-del-tiempo-4x03-bloody-mary-hour/

\section{B i o graph y}

Elizabeth Evenden-Kenyon is a Research Fellow in Medieval and Modern Languages at the University of Oxford. She is also an established consultant in education, politics, and European relations. 